\title{
TESTIMONIAL WAIVER OF THE PRIVILEGE AGAINST SELF-INCRIMINATION AND BROWN $v$. UNITED STATES
}

Laymen and lawyers alike are cognizant of the existence of the privilege against self-incrimination. Furthermore, members of the bar generally realize that the privilege is waivable. However, great confusion seems to exist among both lawyers and our most prominent judges as to what actions constitute a waiver. Waiver is not always the result of a conscious decision to abandon the privilege. The law will often infer a waiver from the conduct of a person despite the fact that he had no intention to relinquish the privilege and regardless of the fact that there was no realization on the part of such person that his conduct amounted to a waiver.

Once the privilege is waived it no longer affords any protection, and refusal to testify becomes a punishable offense. Hence it is important to determine what types of conduct constitute a waiver.

THE CASE

In Brown v. United States ${ }^{1}$ the Supreme Court ruled on the question of waiver of the privilege by a defendant in a civil action. ${ }^{2}$ Although there have been many cases considering waiver by witnesses and criminal defendants the question of waiver by a civil party had not been ruled upon by the Supreme Court since the Arndstein \%. McCarthy cases. ${ }^{3}$ Justice Frankfurter wrote the majority opinion in the Brown case. Unfortunately, the decision is far from unambiguous. The Court's holding is susceptible to two interpretations. One interpretation would indicate that in regard to waiver of the privilege against self-incrimination a defendant in a civil suit occupies the same position as a criminal defendant and waives the privilege by merely voluntarily taking the stand in his own behalf. This interpretation would not radically change the present law but would merely evolve a new rule in an area which previously contained little federal law. ${ }^{4}$ Another interpretation to which the Broven opinion is susceptible is that a witness in a judicial trial waives the privilege by the act of voluntarily taking the stand, regardless of whether or not the testimony given is incriminating. Such a holding would be a radical departure from the past law in this field.

\section{II}

\section{FACTS AND BACKGROUND}

Mrs. Brown came to the United States in 1912 when she was 2 years old. She did not become a citizen until 1946. The Government in this action moved to

1356 U.S. 148 (1958).

2 The case concerned cancellation of citizenship allegedly obtained by fraud. Such an action has been held to be a civil action. Luria v. United States, 231 U.S. 9, 27 (1913).

3 There were three Supreme Court decisions in the Arndstein v. MaCarthy case. Arndstein v. McCarthy, 254 U.S. 71 (1920); McCarthy v. Arndstein, 262 U.S. 355 (1923) ; McCarthy v. Arndstein, 266 U.S. 34 (1924).

4 The Arndstein cases, supra note 3, seem to indicate that a defendant in a civil suit occupies the same position as a witness rather than as a defendant in a criminal case. However, Arndstein was an involuntary bankruptcy proceeding rather than an ordinary civil case. Arndstcin was compelled (McCarthy v. Arndstein, 262 U.S. 355, 358 (1923)) to file a schedule of assets and to testify regarding such assets. Since Arndstein was an involuntary witness, the decision in that case is not inconsistent with Brown. See part IV infra. 
cancei Mrs. Brown's certificate of citizenship on the grounds that it was obtained by fraud. The Government contended that Mrs. Brown lied when in 1946 she stated that during the past 10 years she had not belonged to any organization believing in sabotage. Mrs. Brown was also accused of being a person of bad moral character previous to her grant of citizenship, in that she lied in 1940 when in her affidavit, required by the Alien Registration Act, she stated that she was not active in any clubs or organizations within the past 5 years.5 Mrs. Brown denied these allegations. She conceded that she belonged to the Young Communist League up to January 1935 but insisted that she quit at that time and did not participate further in such activities up to the time of her naturalization.

The United States Attorney called Mrs. Brown as a government witness. ${ }^{0}$ She answered all questions pertaining to pre-1946 activities but refused to answer any questions as to activities taking place after her naturalization. Her claim of the privilege as to these questions was. upheld.7 Defense counsel did not "crossexamine" his client, but later, in presenting his case in chief, he called Mrs. Brown as a defense witness. Mrs. Brown testified that she was "attached" to the Constitution both now and before lier naturalization. She stated that she would be willing to take up arms in defense of the United States and that she never advocated the overthrow of the existing Government or belonged to any organization advocating such overthrow. She also testified that she quit the Young Communist League in January $1935 .^{8}$ The prosecutor then cross-examined her and asked questions pertaining to events occurring after 1946. Mrs. Brown again claimed the privilege, but this time the trial court ruled that she must answer because she had waived the privilege when she took the stand on her own behalf. Upon her continued refusal the district court found her guilty of criminal contempt. In its opinion the district court indicated that the act of taking the stand vaived the privilege. The district court stated that "the same rule applies in civil as in criminal cases and perhaps for stronger reasons." 9

The appellate court refused to base its affirmation of the contempt sentence upon the grounds that the privilege was waived by the mere taking of the stand. It stated that the affirmation was based on the fact that the defendant testified at length in her own defense.10

The defendant inter alia contended before the Supreme Court as well as the district and appellate courts that a defendant in a criminal case does not waive the privilege against self-incrimination unless he testifies to some incriminating facts. 11

5 The Government also alleged that Mrs. Brown lied when she was orally asked during the citizenship proceedings whether she ever belonged to the Communist Party. In addition, the Government charged that Mrs. Brown's oath of allegiance during the citizenship ceremony was given in bad faith. 356 U.S. at 149. The case was brought pursuant to $\$ 340$ (a) of the Immigration \& Nationality (McCarran) Act, 66 Stat. 260 (1952), as amended, 8 U.S.C. 81451 (a) (1958), which provides for cancellation of citizenship obtaincd by fraud.

6 FED. R. Crv. P. 43 (b).

T 356 U.S. at 150.

8 Ibid.

8 Record, p. 34. In addition to the sentence of contempt, the trial court also revoked Mrs. Brown's citizenship. On appeal, only the contempt sentence was challenged.

10234 F.2d 140, 144 (6th Cir. 1956).

11 Brief for Petitioner, pp. 10-19. 
III

THE LAW PREVIOUS TO Brown

\section{A. Criminal Defendants}

An accused in federal court did not have the right to be a witness in his own behalf until $1872 .{ }^{12}$ Since then it has always quite clearly been the federal law that once a criminal defendant takes the stand, he waives the privilege against self-incrimination..$^{13}$ Furthermore, the privilege is waived as to all relevant crossexamination, including that regarding the credibihity of the defendant. ${ }^{14}$ However, the iaw as to witnesses has not been equally clear.

\section{B. Witnesses}

The English rule seems to allow a witness to claim the privilege at any time.15 In the United States the federal rule does not go so far, and witnesses ${ }^{16}$ have often been found to waive the privilege. In the case of an ordinary witness who is not a party to the action, it was clear (at least prior to Brown) that there is no waiver unless the witness testified to an incriminatng fact. ${ }^{17}$ This rule is based on the

\footnotetext{
12 Mayers, Shatr We Asrend the Fifth Amendicent? 18 (1959).

13 Jobnson v. United States, 318 U.S. 189 (1943) ; Rafiel v. United States, 271 U.S. 494 (1926).

14 United States v. Gates, 176 F.2d (2d Cir. 1949) ; Banning v. United States, 130 F.2d 330, 337 (6th Cir. 1942). The cross-examination is governed by the usual federal rules of evidence; bence it is limited to matter opened during the direct examination. This is the rule that Justice Frankfurter seems to refer to when he states that a witness, certainly when be is a party, controls the area of disclosure. See text at note 38 infra. In a criminal case the prosecution cannot call the defendant as a government witness. Therefore, McCormick criticises the application to a criminal defendant of the rule limiting cross-examination to subjects covered on direct because such an application converts a rule usually governing the order of proof into one enabling the accused to limit his examination to sone single phase of the case. McCoranck, CASES ON EviDENCE 220 n.86 (3d ed. 1956); McCorarick, EvideNCE $\$ 26$, at 49 (1954). Although this is a valid criticism, it would appear that the issue ought not to be whether the above rule of evidence is correctly applied but rather the extent to which the defendant must be forced to waive the privilege against self-incrimination in order to be prevented from presenting a one-sided story. See text part V infra. McCormick's criticism would seem to be equally applicable to a civil case if the waiver of a defendant in a civil case applies only when he testifies in his own behalf and not to direct examination by the opponent. Whether the waiver of a civil party testifying in his own bebalf extends to a recall in order to examine such party directly is unclear. Justice Frankfurter's language may indicate that the waiver does not extend so far, for otberwise the witness would not, as Justice Frankfurter states, determine the area of disclosure and inquiry.
}

As to whether a prior claim of the privilege against self-incrimination can be used to impeach the witness, see Grunewald v. United States, 353 U.S. 391 (1957).

15 Regina v. Garbett, 2 Car. \& K 474, 175 Eng. Rep. 196 (Cent. Crim. Ct. 1847).

${ }^{16}$ For purposes of waiver of the privilege against self-incrimination the federal courts seem to make no distinction between witnesses at an adversary and those at a non-adversary proceeding. United States v. St. Pierre, 132 F.2d 837 (2d Cir. 1942), petition for cert. dismissed as moot, 319 U.S. 41 (1953) ; United States v. Haas, 163 Fed. 904 (S.D.N.Y. 1908). But see footnote 15 in Rogers v. United States, 340 U.S. 367, 373 (1951), which purports to reserve this question. A person testifying before a grand jury is always treated as a witness rather than as a defendant, even if an indictment is being sought against such person. United States v. Haas, supra; In re Lemon, 15 Cal. App. 2d 82, 59 P.2d 213 (1936).

17 Rogers v. United States, supre note 16; Isaacs v. United States, 256 F.2d 654 (1958); United States v. Courtney, 236 F.2d 921 (2d Cir. 1956). McCormick states that in order to efiect a waiver the witness must not only have testified to an incriminating fact but must also have had knowiedge of the privilege and a realization that bis testimony was incriminating. MCCorsirck, Evidence $\$ 130$, at 273 (1954). The federal cases do not mention these last two conditions, and it is doubtful whether they are required for waiver in the federal jurisdiction. 
reasoning that once a witness has incriminated himself the privilege no longer serves to protect the witness but continues to obstruct the search for truth. Under this reasoning, since the reason for the privilege has been defeated the privilege should be removed so that the truth may be more readlily ascertained. ${ }^{18}$ The problem has been to determine how incriminating the witness' testimony must be before there is a so-called waiver. The cases seem to lend support to three different tests. One is the "enough to punish" test. The second is the "all elements of the crime" test. The third is the "any incriminating fact." test.

\section{1. "Enough to Punish" Test}

The "enough to punish" test was set forth in the dissent in United States v. St. Pierre (henceforth Pierre II).$^{19}$ In Pierre $I I$ the defendant admitted to a grand jury that he had embezzled some money; he refused, lowever, to state whose money he had embezzled. Unless St. Pierre divulged this information, the prosecutor did not have a case, because the defendant's confession was uncorroborated, and the prosecutor was unable to show a corpus delicti. Judge Frank, in his dissent discussing the history of the privilege, argued that there is no waiver unless the witness has supplied all the evidence necessary for his conviction. This reasoning was based on the fact that the privilege was created to protect from punishment, not from disgrace. ${ }^{20}$ Judge Frank's dissent is important because nearly 14 years later he wrote the majority opinion in United States \%. Courtney, ${ }^{21}$ which opinion substantially expressed the same views as the dissent in Pierre II. In Courtney the defendant admitted that he had distributed gratuities to persons in the garment industry but refused to state to whom these gratuities had been paid. Courtney contended that if it were proved that he paid over $\$ 600$ to any one person be would be guilty of violating the Internal Revenue Code. Judge Frank stated that the defendant did not have to supply the answers that would lead to evidence usable against him, even though he had already stated that he had distributed some gratuities.

Although the decision in Courtney does not mention the fact that Courtney never admitted all the elements of the crime, this nevertheless was the case.22 Hence the facts of Courtney will not support a holding so broad as Judge Frank's statement in the Pierre $I I$ dissent or as might be implied from the language in the Courtney opinion.

\section{2. "All Elements of the Crime" Test}

The "all elements of the crime" test was enunciated by Judge Learned Hand in Pierre II. Judge Hand stated for the majority that at least when a witness admits all elements of the crime, he waives the privilege. The majority held irrele-

18 Foster v. People, 18 Mich. 266, 274 (1869); 8 Wignoro, Evmence $\$ 2276$, at 438 (3d ed. 1940).

19 United States v. St. Pierre, 132 F.2d 837 (2d Cir. 1942), petilion for cert. dismissed as moot, 319 U.S. 41 (1953). This case is referred to as Pierre II because there is another case involving the same parties, reported in $128 \mathrm{~F} .2 \mathrm{~d} 979$ (2d Cir, 1942). See note 23 infro.

20 Judge Frank discusses some of the history of the privilege in his dissent, 132 F.2d at 842. Further excellent historical discussions can be found in 8 WIG2rore, Evidence $\$ 2250$ (3d ed. 1940); Pittman, The Colonial and Constitutional History of the Privilege Against SelfIncrimination in America, 21 VA.L. REv. 763 (1935); Corwin, The Supreme Court's Construction of the Self-Incrimination Clause, 29 Micr. L. REv. 1 (1930).

21236 F.2d 921 (2d Cir. 1956).

22 All the elements of the crime would have to include the fact that Courtney gave at least $\$ 600$ to one individual. 
vant the fact that St. Pierre could not be punished unless he was forced to reveal more information. ${ }^{23}$

\section{3. "Incriminating Fact" Test}

A case which may be considered as standing for the proposition that when a witness admits an incriminating fact he waives the privilege against self-incrimination as to all further details to that fact is Rogers $v$. United States. ${ }^{24}$ However, a close examination of the case tends to raise doubt as to whether either the holding or the opinion, read in its entirety, is that broad. In this case Mrs. Rogers admitted to a grand jury that she was a former secretary of the Colorado Communist Party. Mrs. Rogers was found guilty of contempt for refusing to disclose the identity of the persons to whom she gave the books of the Party.

In the beginning of the opinion Chief Justice Vinson seems to say that once a witness states an incriminating fact, the privilege is waived as to details. ${ }^{25}$ Chief Justice Vinson also cites the Amdstein case, ${ }^{26}$ where the Court used the language that in the absence of admission of guilt or incriminating facts there is no waiver. However, the Rogers opinion goes on to say that in this case there was no danger of further incrimination and specifically points out that all elements of the crine, as well as everything needed for punishment, had been admitted. The Curt emphasized that a conviction for conspiracy can stand although the identity of the other conspirators is unknown. ${ }^{27}$ The exact holding of Rogers is unclear, and authorities have interpreted it in varying manners. ${ }^{28}$

However, the cases following Rogers (the Courtney case ${ }^{2 \theta}$ and the case of In re $\mathrm{Nelson}^{30}$ ) would seem to require that at least all elements of the crime be

$23 \mathrm{It}$ is interesting to speculate as to the defendant's thoughts concerning this opinion. In a recent previous case, his conviction for contempt for refusing to name the persons whose money he embezzled was affirmed on the ground that, since there was no evidence that he had transported the money across state lines, so federal crime was shown. United States v. St. Pierre, 128 F.2d 979 (2d Cir. 1942). The second conviction for contempt, affirmed by Pierre II, was administered after Pierre admitted he took the money across state lines but continued to refuse to tell whose money he embezzled. The first court was composed of Judges Swan, Chase and Frank, the latter writing the opinion. The second court was composed of Judges I. Hand, Clark and Frank, the latter dissenting. A petition for a writ of certiorari in Pierre II was dismissed as moot because Pierre had completed serving his sentence. These decisions give great validity to Justice Black's statement in the dissent in Rogers v. United States, 340 U.S. 367, 378 (1951): "The Court's view makes the protection depend on timing so refined that lawyers, let alone laymen, will have difficulty in knowing when to claim it." See also id. at 378 n.4. England and many States exclude evidence that is secured from a witness by ruling against a valid claim of the privilege. Regina v. Garbett, 2 Car. \& K. 474, 175 Eng. Rep. 196 (Cent. Crim. Ct. 1847); McCoranck, EvmEnce § 127, at 267 (1954). This, however, as the Pierre cases indicate, does not appear to be the federal rule. 8 Wigsore, EvTDExce $\$ 2270$ (3d ed. 1940). But see Boyd v. United States, 116 U.S. 616 (1886) (where the admission of privileged documents secured pursuant to an erroneous court order was held reversible error). Hence, when a federal court incorrectly orders a witness to testify, the witness must either risk jail or abandon the privilege. The rule against illegally obtained evidence and the coerced-confession rule seem not to have been considered where judicial coercion is involved.

21 Rogers v. United States, supra note 23.

25 Id. at 373.

28 Ibid.

27 Id. at 374.

28 Compare Note, 37 Texas L. Rev. 343, 345 (1959), and Comment, 52 Nw. U.L. REv. 542 (1957) with Noonan, Inferences from the Invocation of the Privilege Against Self-Incrimination, 41 VA. L. REv. 311, 326 (1955).

20 United States v. Courtney, 236 F.2d 921 (2d Cir. 1956).

30103 F. Supp. 215 (D.C. Cir. 1952) (no waiver because admission was only as to membership and not as to official position in Communist Party. But see Bart v. United States, 203 F.2d 45, 52 (D.C. Cir. 1952), rev'd or other grourds, 349 U.S. 219 (1954). 
admitted. Their fact situations are not such as to support a holding that everything necessary for punishment must be admitted.

\section{Parties to a Civil Action}

There are only a very few federal cases dealing with the waiver of the privilege against self-incrimination by parties to a civil action.

\section{Plaintiffs}

In the recent decision of Independent Production Corp. v. Loew's, Inc., ${ }^{31}$ the district court granted a motion by the defendant requesting that plaintiff answer some possibly incriminating deposition questions. The court stated that plaintiff waived the privilege by merely bringing the suit. However, the court's opinion did not state whether or not contempt sanctions would be imposed to force an answer. It seemed to indicate that the plaintiff may be given a choice of answering the questions or abandoning the suit. ${ }^{32}$

\section{Defendants}

The principal cases (with the exception of Brown v. United States) ruling on waiver by a defendant in a civil suit are the McCarthy v. Arndstein cases. ${ }^{33}$ Arndstein, who was adjudged an involuntary bankrupt, filed a list of his assets. Upon being questioned further as to such assets, he invoked the privilege. Justice Brandeis, speaking for a unanimous Court, stated that Arndstein did not waive the privilege until he made an incriminating statement. However, it is important to note that Arndstein's examination was involuntary. ${ }^{34}$

\section{IV}

\section{THE BrOwn HOLDING}

Brown is the first Supreme Court case finding a waiver of the privilege against self-incrimination by a civil defendant. Justice Frankfurter's opinion is very unclear and disposes of the problem without discussion of any of the underlying policy considerations. ${ }^{35}$

Mrs. Brown made no incriminating statements at any time. Her whole testimony consisted of denying any criminality or immorality. Justice Frankfurter, speaking for the majority, admits this ${ }^{36}$ but goes on to say that there was a waiver nevertheless. The first part of the majority opinion cites the rules applying to a criminal defendant and states that the same rules apply to a defendant in a civil

3122 F.R.D. 266 (S.D.N.Y. 1958).

32 It seems that plaintiff had dropped one previous suit because its president refused to answer deposition questions that he felt migbt tend to incriminate him. See Independent Prod. Corp. v. Loew's Inc., 24 F.R.D. 19 (S.D.N.Y. 1959).

33 Note 3 supra. However, a footnote in Rogers seems to consider the bankruptcy pro. ceedings as being non-adversary. Rogers v. United States, 340 U.S. 367, 373 n.15 (1951).

34 See note 4 supre.

35 This paper will not cover the policy reasons in favor of and against baving the privilege. These are considered in 8 WIGMORE, Evidence 82251 (3d ed. 1940); MAXERS, SHALI WE AMEND the Fiftr Adiendatent? (1959); Griswold, The Fifth Aatendarent Today (1954); Clapp, Privilege Against Incrimination, 10 RuIGers L. REv. 541 (1955). However, this paper will discuss the policy considerations tbat should be considered in connection with waiver, assuming that the privilege is part of our law. See text part V infra.

38356 U.S. at 154. 
suit who voluntarily takes the stand. ${ }^{37}$ The next part of the opinion distinguishes between a voluntary and an involuntary witness. It is not absolutely clear, but it is hoped that Justice Frankfurter, in distinguishing between a witness compelled to testify and one who testifies voluntarily, is referring to witnesses who also are parties. Justice Frankfurter says:

A witness who is compelled to testify, as in the Arndstein type of case has no occasion to invole the privilege against self-incrimination until testimony sought to be elicited will in fact tend to incriminate .... .

On the other hand, when a witness voluntarily testifies, the privilege against selfincrimination is amply respected without need of accepting testimony freed from the antiseptic test of the adversary process. The witness himself, certainly if he is a party, determines the area of disclosure and therefore of inquiry. Such a witness bas the choice, after weighing the advantage of the privilege against self-incrimination against the advantage of putting forward his version of the facts and his reliability as a witness, not to testify at all. 88

This language could be interpreted as applying to any witness who testifies without having formally been subpoenaed..$^{39}$ It must be kept in mind, however, that the Court had before it a case in which the witness was also a party. The whole tenor of the language reprinted above emphasizes the existence of a choice either to testify or not to testify. In the instant case Mrs. Brown could not be compelled to testify in her own behalf. However, a person who can be subpoenaed has no true choice not to testify at all, yet this choice is the rationale given for considering the taking of the stand as a waiver. Justice Frankfurter certainly would not insist upon a mere formal refusal by a person who can eventually be forced to testify. The distinction the Court most probably is trying to make is one between a witness who is involuntary in the sense that his testimony is legally compellable and a witness who is voluntary in the sense that he cannot be compelled to testify by the party calling him.

If the language of the decision is interpreted to mean that any witness not compelled to testify by the actual service of process waives the privilege by taking the stand, then this dictum would be totally unsupported by the prior cases. Such a radical departure from the present law would certainly be stated more clearly. Furthermore, such a rule would seem somewhat inconsistent with one of the major policy considerations in favor of the privilege, i.e., encouragement of witnesses to testify. ${ }^{40}$

As to a party who is compelled to testify, Justice Frankfurter feels that such a party may claim the privilege whenever the questions asked do in fact tend to incriminate. ${ }^{41}$ Whether Justice Frankfurter is here incorporating the former federal rules as outlined in Courtney to waiver by witnesses or is expounding the "any incriminating fact" rule is unclear.

As to a witness who "voluntarily" testifies, the majority at first indicates that the mere act of taking the stand waives the privilege. However, near the end of the majority opinion, Justice Frankfurter states that Mrs. Brown did not waive the

37356 U.S. at 155.

38 lbid. It is interesting to note that when Justice Frankfurter stated that a witness who is a party determines the area of disclosure he seems to recognize a partial privilege against self-incrimination for a party who takes the stand. See note 14 supra.

${ }^{39}$ See Note, 37 Texas L. REv. 343, 346 n.17 (1959).

408 WigMORE, EVDENCE 82251 (3d ed. 1940).

11356 U.S. at 155. 
privilege by merely taking the stand, but did so by testifying in her own behalf." How this statement modifies the prior one is not at all clear, unless Justice Frankfurter wanted to reiterate the difference between an ordinary witness and a party.

\section{$\mathrm{V}$}

\section{CRITIQUE}

It is unfortunate that the Browen case, as have the cases before it, attempted to formulate purely mechanical rules as to waiver of the privilege against selfincrimination. It would appear that a preferred approach would be to analyze the particular situation presented and to require in each cise the minimum amount of waiver necessary for fairness to all the parties. Only in this way may full scope be given to a valuable constitutional protection as well as to the conflicting policy considerations. This, in effect, was the approach of Justice Black, speaking for the minority.

In order to achieve this result, the mechanical tests of "taking the stand" or "admitting an incriminating fact" should be totally abolished. The homogeneous grouping of adversary and non-adversary proceedings should also be abandoned.

In order to give effect to the principle of minimum waiver consistent with fairness to all the parties, different treatment should be given to a witness at a nonadversary (perhaps better referred to as an investigatory) proceeding from that given to a witness at an adversary proceeding. This is not presently the case, although a footnote in the Rogers case purports to reserve this question. ${ }^{43}$ The policy considerations for finding a waiver are much weaker in an investigatory proceeding, such as a grand jury or a congressional committee hearing, than in an adversary proceeding. The only right prejudiced by the invocation of the privilege in an investigatory proceeding is the right of the public body to obtain the information sought. On the other hand, the policy in favor of the privilege would seem to indicate that there should be no waiver in this type of proceeding so long as the answer sought might tend to further incriminate.14 It is in this type of situation that the present rationale of waiver (that waiver results from the notion that once the witness testifies to an incriminating fact there is nothing left to protect) is most applicable. ${ }^{45}$ If the witness has admitted everything necessary for his punishment, the public right to the information should be given paramount weight. In such a situation the invocation of the privilege is usually motivated by a desire to protect others, for which purpose there is no privilege. But until everything necessary for punishment has been admitted, the privilege should continue to protect the witness against the only danger that the privilege was ever created to protect, i.e., punishment. ${ }^{48}$ Furthermore, the policy consideration of the public's right to the information is better served by not forcing the witness to invoke the privilege at the earhest possible time. ${ }^{47}$ In an investigatory proceeding the public

42 Id. at 156.

43 See note 16 supra.

44 The privilege grew from resistance to the ex parte type of investigation. The policy reason for having the privilege in this type of investigation is that of protecting the freedom and privacy of the individual. See authorities cited note 35 supra.

45 See text at note 18 supra.

46 United States v. St. Pierre, 132 F.2d 837 (2d Cir. 1942) (dissenting opinion by Frank, J.). Of this dissent Wigmore says: "The masterful dissenting opinion of Frank, J, is worthy of serious consideration." 8 Wigmore, Eitdonce $\$ 2276$ (Supp. 1959, at 164).

47 Encouragement to give testimony is one of the major reasons given for extending the privilege to witnesses. 8 Wigsore, Evidence $\$ 2276$ (3d ed. 1940). 
is not prejudiced as would be an opposing litigant by the use of the privilege to prevent testing the truth of the statement, since the investigatory body undoubtedly will give little weight to statements where cross-examination is precluded by invocation of the privilege. ${ }^{48}$

In an adversary proceeding the policy considerations are totally different. Here a witness should not be allowed to prejudice a case by making a damaging statement and then plead the privilege when an attempt is made to test the truth of such statement by cross-examining him. However, our present rules fail to give full effect to the policy in favor of cross-examination. So long as the witness' statements on direct are not incriminating, he may claim the privilege if an incriminating question is asked upon cross-examination. The opposing party may be prejudiced very seriously by the witness' statements, but his only remedy lies in having the testimony stricken. ${ }^{40}$ The reason usually given for allowing a witness to invoke the privilege when the first incriminating question is asked is that he cannot invoke it before that time..$^{50}$ This reasoning is poor since it ignores the fact that the word "incriminating" really has different meanings, depending on whether it is used in the context of claiming or that of waiving the privilege. ${ }^{51}$ Furthermore, this reasoning assumes the conclusion. The only reason a witness cannot invoke the privilege earlier is that the Court says so. However, it is submitted that the rule should be changed to allow a witness to invoke the privilege if questions as to the details concerning his answer will tend to incriminate him. Once he makes a statement, he should be considered as having waived the privilege with respect to any cross-examination questions concerning details of his answer that he could reasonably have anticipated, regardless of whether or not his original answer was incriminating. However, he should be allowed the privilege as to cross-examination questions dealing with other matters or as to questions dealing with his general credibility. ${ }^{52}$

A party to a civil action occupies a position slightly different from that of a witness. It is perhaps fair to hold that a plaintiff to an action waives the privilege

18 The most serious problem in this situation would be the possible lessening of public pressure, which, under the present rules, may force some persons to waive the privilege. However, by not forcing a witness to plead the privilege at the earliest possible nioment, perliaps much information otherwise lost will be obtained. On the question of public pressure, see also Quinn v. United States, 349 U.S. 155, 164 (1955).

19 Hammond Packing Co. v. Arkansas, 212 U.S. 322, 349-54 (1909); Brown v. United States, 356 U.S. 148, 160 (1958) (dissenting opinion); 5 WrGMORE, EvmENCE $\$ 1391$ (3d ed. 1940); MCCORMICK, EvEENCE \$ 19, at 41 (1954). Where the witness claiming the privilege on cross-examination is not a party to the action the renuedy of striking the direct may be denied. United States v. Toner, 173 F.2d 140, 144 (3d Cir. 1949); McCoramce, Evionerce \$ 19, at 41 (1954).

50356 U.S. at 155.

5I In order to claim the privilege, the question need only be a link in a chain. It need have no incrininating effect by itself. Simpson v. United States, 355 U.S. 7 (1957), reversing per curiam Simpson v. United States, 241 F.2d 222 (9th Cir. 1957), Wollam v. United States, 244 F.2d 212 (9th Cir. 1957), and Mackenzie v. United States, 244 F.2d 712 (9th Cir. 1957), on the basis of Hoffinan v. United States, 341 U.S. 479 (1951). See Ratner, Consequences of Exercising the Privilege Against Self-Incrimination, 24 U. CEr. L. REv, 472, 479 (1957). However, there is no waiver unless the answer to a question at the very least admits some element of a crime. See text part III supra. But see MCCormick, Evmence $\$ 130$, text at 273 n.3 (1954), where McCormick seems to feel that the word "incriminating" is equivalent in both situations.

52 See text note 14 supra. In order to protect the cross-examining party, an inference of noncredibility should be allowed if a witness pleads the privilege when a question dealing with his credibility is put to him. An inference that a party's testimony on subjects within his knowledge would be unfavorable is presently allowed against a civil party who fails to testify. Bilokumsky v. Tod, 263 U.S. 149, 153-54 (1923). 
as to all relevant questions concerning his cause of action. But it is highly doubtful whether relevant questions should include questions concerning general credibility. Certainly a plaintiff should not be allowed to hide material facts concerning his cause of action. But should a person of bad character be barred from the courts on issues totally unrelated to his suit, except as they shed light on his credibility? In any event the courts could allow an inference against credibihty were a plaintiff to invoke the privilege in response to questions challenging his credibility. ${ }^{53}$ The defendant would then be substantially protected, and the plaintiff would not be punished collaterally for activities having nothing to do with the suit. It hardly seems just to refuse a person a divorce or an action on a contract on the ground that he may have committed a misdemeanor or crime completely unrelated to the cause of action.

The above considerations apply with even more force to a defendant. It seems unjust to place a civil defendant in a position in which he must either surrender his right to testify or waive his constitutional right of protection against selfincrimination. ${ }^{54}$ In Brown the questions were relevant to the cause of action, ${ }^{55}$ and therefore, assuming the past cases classifying this type of proceeding as a civil action are proper, a finding of waiver was just. However, Justice Frankfurter's opinion would seem to be much too broad, since the federal rule at present is that once there is a waiver, the privilege is waived as to all questions, even as to those relating to credibility. ${ }^{38}$

Even though a finding of waiver in Brown was perhaps proper, the decision certainly did not give effect to the principle of minimum waiver consistent with justice to all parties. In an investigatory proceeding the inost effective means of protecting the public right to the information sought is civil or criminal contempt. The same consideration is perhaps true when dealing with a witness who is not a party to the action. But when dealing with a party, judgment for the other side or a permissible inference that the answer would be unfavorable would fully protect all the parties. ${ }^{57}$ No policy consideration ${ }^{58}$ is served by imprisoning the defendant unless he answers.

In a criminal case the court cannot direct judgment for the prosecution. Hence, criminal or civil contempt should be allowed to compel an answer whenever permitting an unfavorable inference would be inadequate. However, as to questions of general credibility, an inference against credibility should be sufficient.

\section{CONCLUSION}

The Brown decision has continued the mechanical approach of earlier cases in regard to the question of waiver of the privilege against self-incrimination. Re-

53 See note 52 supra.

54 Justice Black underscores this injustice in his dissent in Brown by observing that a civil defendant's failure to testify may be used against him as evidence of the most persuasive character. 356 U.S. at 159. Cf. Bilokumsky v. Tod, 263 U.S. 149, 153-54 (1923).

55 Questions as to activities after naturalization are relevant to show an applicant's disposition before naturalization, especially when he continues a course of conduct begun before naturalization. Knauer v. United States, 328 U.S. 654, 668 (1946); Orth v. United States, 142 F.2d 969, 973 (4th Cir. 1944).

36 Note 13 supra. But as to witnesses, ef. Krogmann v. United States, 225 F.2d 220 (6th Cir. 1955).

57 See Justice Black's dissent in Brown, 356 U.S. at 160.

58 The argument of vindicating the dignity of the court is sometimes advanced. However, such dignity would seem to be amply vindicated by allowing an inference for the other party or by giving judgment to such other party. 
gardless of whether one likes or dislikes this privilege, it would seem that so long as it is enshrined in our Constitution, the doctrine of waiver should bear a rational relation to the purpose of the privilege. Waiver of constitutional privileges should not be readily inferred.$^{52}$ It is hoped that the next case dealing with this problem will consider the underlying policy considerations and adopt a rule of minimum waiver consistent with fairness to all the parties.

Gary A. Schlessinger

69 Emspak v. United States, 349 U.S. 190, 196 (1955); Smith v. United States, 337 U.S. 137 (1949); Glasser v. United States, 315 U.S. 60, 70 (1942). 